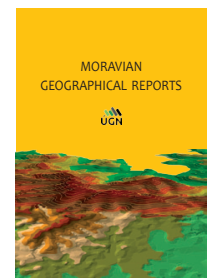

MORAVIAN GEOGRAPHICAL REPORTS

The Czech Academy of Sciences, Institute of Geonics

journal homepage: http://www.geonika.cz/mgr.html

doi: https://oi.org/10.2478/mgr-2020-0017

\title{
What about Time-Geography in the post-Covid-19 era?
}

\author{
Pavel KLAPKA a *, Kajsa ELLEGÅRD ${ }^{b}$, Bohumil FRANTÁL ${ }^{c}$
}

\begin{abstract}
In this year, 2020, the Covid-19 pandemic has imposed new challenges for most human activities. Timegeography is a theoretical approach with great potential for analysing the consequences of the new disease and other disturbances, and this article aims at identifying possible developments of interest for the approach in the post-Covid era. The article addresses challenges that emerge for time-geographic research from the perspective of massive changes in human behaviour, regarding time-space activity patterns, caused by the globally diffusing disease. The implications of the pandemic are discussed with respect to four areas: (i) timegeographic techniques; (ii) activities and rhythms; (iii) activity spaces; and (iv) social issues and perceptions. The time-geographic concepts to be scrutinised are constraints, virtual time space and bundles, and stations and paths. In addition, the article introduces this Special Issue of the Moravian Geographical Reports on 'Current issues, methods and applications in time-geography', contributions which for evident reasons were written before the onset of the pandemic.
\end{abstract}

Key words: time-geography, Covid-19, pandemic, spatial behaviour, time-geographic concepts, future research prospects

Article history: Received 30 September, Accepted 30 October, Published 31 December 2020

\section{Introduction - Time-geography: Evolution and 'revolution' in the field?}

Time-geography was developed by the Swedish Human Geographer Torsten Hägerstrand (1970, 1974), and the principles, concepts and ontological background of timegeography draw on his earlier works (e.g. Hägerstrand, 1953, in English 1967). His PhD work (1953) was on the chorology of the diffusion of innovations, introducing a processual time dimension and quantitative methods into Human Geography. He also developed methods to more precisely locate objects and places by introducing coordinates (Hägerstrand, 1955), thereby grounding what later evolved as Geographical Information Systems (GIS). This research was inspired by his earlier work on migration and theorizing on migration chains (Hägerstrand, 1950, 1957).

Just like any other field of geographic inquiry, the timegeographic approach has developed through time and new vistas were envisaged (see overviews, outlines, discussions and prospects: Lenntorp, 1976, 1999, 2004; Pred, 1977, 1984; Thrift, 1977; Mårtensson, 1979; Thrift and Pred, 1981; Carlstein, 1982; Hägerstrand, 1982, 1985, 2009; Hallin, 1991;
Gren, 2001; Timmermans et al., 2002; Miller, 2005a; Yu and Shaw, 2007; Couclelis, 2009; Neutens, et al., 2011; Frantál, et al., 2012; Sui, 2012; Dijst, 2019). Two recent monographs by Ellegård (2019a, 2019b) present the development of and state-of-the-art in time-geography in the pre-Covid era. The global Covid-19 pandemic, a 'revolutionary' moment for the current status of many disciplines, evokes new challenges and examinations of some recent directions in time-geographic research. The point of departure is the overt and covert changes and adaptations in human behaviour to a new geographical societal context and its anchoring in the time-space.

As emphasised by Poom et al. (2020), the current global crisis is clearly spatial in nature - the virus outbreak, hot spots, mitigation measures, closed borders, quarantines and related societal impacts are all profoundly about distance, separation and space. This has offered geographers opportunities for analyses of the relevant issues through a geographic lens and predestined them to play a significant role in the fight against the pandemic (see Aalberset et al., 2020; Rose-Redwood et al., 2020). Geographical

\footnotetext{
${ }^{a}$ Department of Geography, Faculty of Science, Palacký University, Olomouc, Czech Republic (*corresponding author: P. Klapka, e-mail: pavel.klapka@upol.cz)

${ }^{\mathrm{b}}$ Department of Thematic Studies (TEMA), Technology and Social Change (TEMAT), Linköping University, Linköping, Sweden

${ }^{\mathrm{c}}$ Department of Environmental Geography, Institute of Geonics, The Czech Academy of Sciences, Brno, Czech Republic
} 
knowledge, GIS and spatial analysis have already proved to be important for understanding the pandemic's reach and impacts (see the extensive review by Franch-Pardo, et al., 2020).

Given the present state of knowledge, the ongoing directions of changes in behaviour due to Covid-19 (living strategies, attitudes, perceptions, etc.) of individuals and society are difficult to predict, in the long term as well as the short term. Now, when the vaccine is available, who will get it, when and at what cost? The same applies for any suggested therapeutic remedy. What will be the economic costs and impacts of the pandemic? What will the political costs be? Which population groups will be affected more and which less? Which places will be affected more and which less? These are some questions regarding the uncertainty of the future. The pandemic, its diffusion, consequences and impacts represent distinct spatial and temporal phenomena. The answers for the questions will certainly be different at global, regional and local levels. Thus, we maintain that the post-Covid world will bring about new requirements for time-geographic research, and that some time-geographic concepts and methods will gain increased importance and that some of them, partly forgotten or left aside, will have to be reappraised and rethought once again.

The objectives of this introductory article to this Special Issue of the Moravian Geographical Reports are two-fold. First, it aims at identifying possible developments of interest for the time-geographic approach in the post-Covid era. Second, it will present original articles in the issue, which for evident reasons were written in the pre-Covid era. To fulfil the first objective, this article refers to several extensive and excellent earlier works outlining time-geographic concepts, methods and techniques and the history of the approach, besides reflecting on time-geography in the new situation caused by the pandemic. Conceived as a text pointing to some new avenues in time-geographic research, we attempt to revise the importance and meaning of several time-geographic concepts and to turn attention to some of the time-geographic methods and techniques that we find promising for future research.

We think that it is just the right time to open the discussion of further reconsideration of time-geography. Thus, this current introductory article strives to do so with modesty, as concluding opinions should get ripe first. The second section discusses the traditions of and the challenges to time-geography in the context of the global pandemic. The third section is on some possible prospects for post-pandemic time-geographic research and what, in our opinion, could become possible new research avenues. The fourth and final section introduces original time-geography inspired articles written by researchers from different parts of the world and from a variety of different research disciplines. They are all written in the pre-Covid era and as such they may serve as points of departure for time-geographic research directions in the post-Covid era.

\section{The Covid-19 pandemic: Implications for time-geography?}

The new situation, which is the result of the global uncertainty related to the ongoing pandemic, calls for deliberate discussions of future time-geographic directions and relevance. It also brings about new challenges to timegeographic research, its theory and concepts. In this section we put forward some ideas in this respect. We proceed from overt to more covert aspects of time-geographic research, beginning with a discussion of time-geographic techniques, going on to the issue of routine and random activities, to the role of virtual space, and concluding with social issues and perceptions.

\subsection{Time-geographic techniques to understand time-space processes}

In the core of time-geography is the assumption of the existence of indivisible individuals in the time-space. The historic existence of any indivisible individual can be recorded as a path (or individual path) in the timespace, when a geographical location and time is known for virtually every point along this path. In time-geography, an indivisible individual can be either a human, an animal or a thing, thereby enabling analysis of the relations between humans and other subjects and objects in the environment (Hägerstrand, 1970, 1974, 1976, 2009). The path concept relates to various volumes of time: a moment, a day, a week, a month, a year, a life time, during which the existence of an individual (and for humans, also other dimensions such as her activities, attitudes, perceptions, feelings, etc.) is tracked. From the earliest years of time-geographic research, timespace diaries (also time-space budgets, activity timetables), were usually filled out by individual respondents. They combine traditional time use diaries with spatial movements and locations, and occasionally emotions and health indicators (Ellegård, 2020).While this personal handling of the time use diary is advantageous when one attempts to reveal the subjective bases of human behaviour, then there is a risk that the same subjectivity can bias the precise record of a path in the time-space. This will be discussed further.

The principle of tracking an individual's time-space existence can be suitably used when we face the diffusion of communicable diseases, such as Covid-19. In this respect, we deem the time-geographic technique recording the activities and movements of individuals in time and space very useful when health issues emerge (see, for example: Gao et al., 2020; Oliver et al., 2020). Moreover, the spread of a communicable disease is in fact also a time-geographic problem - that of the diffusion of phenomena in the time-space (as noted above, individuals in time-geographic research are not necessarily human beings). There is then a direct link to Hägerstrand's (1953) innovation diffusion theory. Here, it is not the mere path concept, which is useful. When backtracking an infected person, her physical contacts with others are important. This is nothing more than the well-known time-geographic concepts of encounter, couplings, bundles and groupings, which are partly the result of coupling constraints. The theoretical concept of spatiotemporal proximity (Yuan et al., 2018) gives us a more thorough basis for this issue, together with the notion of random encounters to be estimated (Long, 2018; Yin et al., 2018).

In order to acquire utilisable information on the timespace movements and activities of an infected person, which is a necessary condition for the so-called smart quarantines, reliable methods of backtracking in time and space are needed. As we have hinted above, time-space diaries can be biased by the subjective way they are completed. Today, widely-available communications technologies (such as mobile phones and smart watches with Internet access, Bluetooth and GPS modules) can be used to reconstruct sufficiently the time-space existence of individuals and their contacts and interactions, as long as they carry their communication tools with them. Time-geographic research 
has a long experience with such tracking (e.g. Kwan, 2004; Yu, 2006; Shaw et al., 2008; Shoval, 2008; Chen et al., 2011; Šveda and Madajová, 2012, 2015; Shoval et al., 2014; Thulin and Vilhelmson, 2019). There are risks related to tracking technologies and we want to point to the issue of individual data protection, privacy and more general issues of power and human rights. A key concern seems to be that the pandemic has been used to create and legitimise surveillance tools used by governments and technology companies. This is likely to persist beyond the emergency, and the data may be used for purposes such as hyper-targeting by private companies and/or law enforcement by governments, which may be particularly dangerous in less democratic countries (cf. Ellegård, 2019a; Oliver et al., 2020).

\subsection{Routines, rhythms and random activities in time space}

Individual paths include temporal and spatial dimensions. If only the time coordinate changes, the person finds herself at a 'station'. As space is heterogeneous, the fulfilment of one's needs, desires and duties ('projects') implies also the necessity of spatial movements. Here we come to the term 'mobility' in the time-space (Vilhelmson, 1999). Individual movements can include routine activities (everyday activities - see e.g. Ellegård, 1999) and random activities. Taking into account the anchor point theory (Golledge and Spector, 1978; Couclelis et al., 1987) and the principle of return (Lenntorp, 1976; Hägerstrand, 1985; Ellegård and Vilhelmson, 2004), routine activities are logically much more frequent in individual lives than random activities. In this respect, such stations as home, workplace and school are typical anchor points (others have a more or less temporal and ephemeral character). Routine activities have different rhythms (cf. Lefebvre, 2004) - daily, weekly, monthly or yearly. Typical rhythms relate to shorter time periods (daily and weekly rhythms) and include travels to work and school, partly also shopping and some short-term leisure activities. In contrast, many random activities are related to tourism issues.

In time-geography, the concept of authority constraints concerns rules, laws and recommendations set up by authorities that people involved in the domain of the authority in question, are expected to follow. For example, Covid-related lockdowns and other measures taken to negotiate and mitigate the impacts of the pandemic, severely interfere with peoples' usual rhythms and the mobility timespace patterns of a substantial part of population (however, there are certain differences among countries in the rigidity of these measures). As a consequence, daily mobility patterns are affected by utilising the possibilities of a home office and telecommuting (cf. for example, Asgari et al., 2019; Thulin et al., 2019), on-line teaching, shopping, etc. Such everyday activities are related to the issue of virtual performance (see Section 2.3).

The attenuation of economic as well as social activities, together with reduced mobility, has brought to the fore some temporary common environmental benefits (e.g. reduction in carbon dioxide emissions, etc.). In contrast, the costs related to environmental issues have been transferred to particular households, as homes have become extensively 'frequented' stations. In this respect, the resource consumption and energy behaviour of households are gaining particular importance (cf. for example: Frederiks et al., 2015; Isaksson and Ellegård, 2015; Palm et al., 2018; Köhler and Trygg, 2019). The aggregate effect of many households using energy-intensive electrical appliances (such as air- conditioning or space, water heaters and increasingly computers, "smart phones" and servers) concurrently, can contribute to new and higher peak demands on the electricity network. At the same time, the rapid development of renewable energy technologies, varying in time and season, is likely to exacerbate the temporal mismatch between supply and demand, causing many countries to consider how future energy systems might be managed (cf. Suomalainen et al., 2019).

\subsection{Physical existence and virtual time-space}

The anchor point theory, the principle of return, mobility patterns and rhythms, bring us to the issues of individual and aggregate existence in the time-space, to (daily) activity time spaces, and to a space-time fixity of activities (Schwanen et al., 2008; Shen et al., 2015). While paths between anchor points and other stations define activity spaces with regard to the past, the potentially accessible part of the time-space defines possible activity spaces with regard to the future. The time-geographic concept for this phenomenon is the prism (Hägerstrand, 1970; Lenntorp, 1976). The shape of a prism is influenced both by the current location of the individual and by her future anchor points, following the principle of return. Another time-geographic core concept that can be related to this vein of thinking is pocket of local order (Hägerstrand, 1985; Ellegård and Vilhelmson, 2004). It stands for a place that is organised, scheduled and physically equipped to facilitate the performance of individuals' activities to achieve the goals of their projects.

There are efforts to work with individual prisms in order to reach generalisable results. Yuan et al. (2018) proposed the so-called space-time regions, while Lee and Miller (2019) put forward the concept of the average space-time prism. Liao (2019) defined potential space-time path areas. Moreover, the aggregation of individual activity spaces based on pairs of anchor points (home - workplace, home school, etc.) are in fact related to the extensively researched issue of functional regions (for the concept: see for example, Klapka and Halás, 2016; for definition and use: see Klapka et al., 2014, 2016). Functional regions are largely based on regular rhythms of movements, such as daily travel-to-work and travel-to-school flows. Under specific circumstances these regions are called daily urban systems, local labour market areas, etc.: we propose the general term daily spatial systems, which in fact is very close to the time-geographic concepts of an activity space, pocket of local order and prism. All of these concepts can represent a suitable basis for political decision making, when the question of (smart) spatial lockdowns arises, particularly in an intra-state context. The use of prisms, space-time path areas, functional regions and daily spatial systems for deciding on measures to mitigate diseases could have one significant advantage: it should have the least effect on every day economic and social lives.

Activities in the virtual environment have only started to be discussed and analysed relatively recently (Miller, 2005b; Vilhelmson and Thulin, 2008; Yu and Shaw, 2008; Couclelis, 2009; Thulin and Vilhelmson, 2012). It is closely related to the already-mentioned issue of information and communication technologies (Graham, 1998; Thulin and Vilhelmson, 2005; Schwanen and Kwan, 2008; Shaw and Yu, 2009), which provide one with necessary technological background. The current situation of the ongoing pandemic and its presumed consequences seems to acknowledge and further emphasise the importance of the concept of virtual 
space. Such technologies make it possible for people to perform activities that formerly needed transportation to another place, now without moving physically. This brings to the fore the detachment of places (stations) from activities (in projects) in the form of on-line shopping, on-line teaching, etc. (bundles in virtual time space), it can add to the decrease of physical mobility and physical contacts, and it enables one person to restrict their social contacts and activities to a certain extent. When purchases are involved, however, someone else has to transport the good to the customer Time-geographic diary-based studies of daily life facilitate understanding such consequences of Covid-19, since the time-geographic diary methodology builds on detaching activity from place (and other dimensions of daily life) in order to contextualise these in the analytical stage of the investigation (Ellegård, 2019a).

\subsection{Social issues and perceptions}

Social issues, feelings, perceptions and emotions already represent a viable part of time-geographic research and frequently use the approaches of relational geography (see for example, Hall, 2019). The interactions between individuals within pockets of local order and activity spaces can be seen as departing points (cf. Liu et al., 2018; Dixon et al., 2020). Thus, 'carescapes' related to children, the disabled, the elderly and women can be discussed (e.g. Dyck, 1998; Davies, 2001; Wiles, 2003; Yantzi and Rosenberg, 2008; Bowlby, 2012; Craig and van Tienoven, 2019; Landby, 2019). The issues of loneliness, social and socio-spatial exclusion and segregation emerge right away (Schnell and Yoav, 2001; Schönfelder and Axhausen, 2003; Lee and Kwan, 2011; Shen, 2019; Dixon et al., 2020; Frantál and Klapka, 2020). The emotive load of stations and paths is discussed by McQuoid and Dijst (2012). The references from a variety of disciplines indicate that these issues are not unique to time-geographic research, but there is a common ground in everyday activities and activity spaces, which are distinct time-geographic concepts.

The global pandemic clearly affects social issues and the perceptions of individuals. Social contacts are limited and social distancing (which also is geographic) is recommended. This can increase the feelings of loneliness and social exclusion, particularly for the elderly, single mothers, single men and women, persons on parental leave, disabled persons, etc. (see for example: Brooke and Jackson, 2020; Gao and Sai, 2020). The results of an extensive study from France show that during the lockdown, most people have experienced a slowing down of time, which was not explained by the levels of perceived stress or anxiety (although these were considerable), but rather by the increase in boredom and sadness felt in the lockdown situation (cf. DroitVolet et al., 2020). Manzo and Minello (2020) report how the increase in remote working during the lockdown has created unequal domestic rearrangements of parenting duties with respect to gender relations. They highlight the key role that working mothers have played in creatively and effectively organising caretaking activities to resist the burden of social distancing, child-care, and maintaining a degree of 'normalcy'.

The "virtualisation" of social contacts is for most people probably an unsatisfactory and imperfect solution (Gao and Sai, 2020). For instance, older adults do not command the information and communications technologies (ICTs) as younger generations (in general) do and their feelings of isolation are accordingly not helped (cf. for example,
Thulin, et al., 2020). Additionally, the issue of care of other persons in need (children, the disabled, the elderly) emerges. Kindergarten and school closures make it difficult to combine care and work, which can compromise the economic situation of families and households. Moreover, it has been found that there exists a wide disparity amongst sub-populations, such as those with higher incomes who are able to access technologies that can ensure continuing education and social contacts digitally during isolation (Nicola et al., 2020).

\section{Post-pandemic time-geography: Future prospects?}

The pandemic event of 2020 will affect time-geographic research and its future prospects, just as most likely the case for many sciences and the arts. Before returning to the issues touched upon above, we will discuss some points that might be of interest when redefining, expanding and stressing some of the future prospects for time-geographic research.

Beforehand, it might be useful to hint very briefly at some philosophical and psychological implications of the 2020 global pandemic. This event, not experienced by many if not most ever before, affects the feelings, the emotions and the attitudes of individuals and society. It brings more fear, worries and anxieties than joy, relaxation and contentedness to existential emotions (see also Dijst, 2019). These emotions are reflected in human needs, values, goals and 'projects' that may be 'violated' by the pandemic, in comparison to the situation just a year ago. Even though further discussion of the philosophical and psychological implications is well beyond the scope of this article, individual emotions are certainly reflected in social mood as shared (i.e. aggregated) states of mind.

The satisfaction of human needs and values and the achievement of goals rest on the fulfilment of the activities necessary to reach the goals of specific 'projects', as formulated by individuals and manifested in their activities. These are necessarily anchored in the time-space, wherein people interact with other persons and objects in the geographical environment. This is clearly reflected in behaviour in time space and time space behaviour (also referred to just as spatial behaviour: Golledge and Stimpson, 1997). While projects in the time-space are directly related to efforts to fulfil one's needs and to accomplish the goals of one's projects, the time-space behaviour manifests the spatio-temporally overt activities of individuals. The former concept includes strategies to satisfy one's demands and hopes and is based on spatial cognition and spatial choice, while the latter concepts include concrete steps carried out in time space to realise the strategy based on spatial interaction and spatial mobility concepts.

\subsection{The use of constraints}

Time-geography includes a system of constraints, usually classified into three main groups: authority, capability and coupling constraints (Hägerstrand, 1970), which play an important role in analysing human life. While concepts similar to authority and capability constraints appear in most social sciences, the coupling constraints are unique to time-geography. All three types of constraints are of value in the new pandemic situation.

As indicated above, the concept of authority constraints has gained some new qualities. It suffices to take examples from Europe, where we have witnessed numerous examples of lockdowns, quarantines and reactivation of state borders 
in the Schengen Area by the overall authorities - a situation not seen since the fall of the Iron Curtain. Not only tourism travel, but also everyday activities have been affected by these constraints, including work, education, shopping and socialising. Thus, adaptation strategies to the socio-spatial restrictions are a very appealing theme for time-geography.

The definition of capability constraints has not changed much during the past decades. Hägerstrand (1970, p. 12) says that "Capability constraints' are those which limit the activities of the individual because of his biological construction and/or the tools he can command". Further, Ellegård (2019a, p. 44) states that "Capability constraints concern the individual's opportunities related to her bodily and mental functions...". Attention should be paid to 'mental functions' in the latter definition. The global pandemic has shown that there are psychological, and consequently behavioural, constraints of an intrinsic quality that prevent individuals from fulfilling their needs and the goals of their projects. They are related to fear and worries and they are clearly manifested in individual paths. Individuals may tend to think twice about the way to accomplish their projects (see also Section 3.3).

The concept of coupling constraints, which will be discussed in the following subsection, concerns the opportunities for individuals to meet and interact in the time-space when necessary for performing activities that will help them to achieve the goals of their projects. The pandemic makes it more difficult to meet physically and, in this respect, we can refer to the already-mentioned issues of isolation and loneliness (see Section 2.4). In contrast, Tyner and Rice (2020) suggest that the pandemic offers people an opportunity to think more deeply about their lives, who and what they value in society towards achieving meaning in life.

\subsection{Role of virtual bundles}

Many everyday activities have been transferred to a virtual world, even though the individuals (as human bodies) are always (time) located somewhere (place). On the one hand, such a virtual world enables one to mitigate the feelings of isolation and loneliness, but, on the other, coupling constraints have significant drawbacks concerning some projects.

On-line shopping, for example, involves many new kinds of couplings with qualitatively different consequences compared to shopping in the grocery store. The on-line shopping customer stays at home (decoupled from the shop) and sends the order to the shop. Then someone else picks and packs the goods (they couple the goods into a specific bundle), and thereby this someone decides what quality of a specific good that is chosen. Then, someone else transports the goods to the customer's home, in order to couple them to the customer. Hence, the goods are coupled to many different persons and places on the way to the customer. The on-line shopping, then, involves more physical couplings than inthe-shop shopping.

Our personal experience from teaching and research can bear witness to some of the negative effects. Recent lecturing activity has shown that personal contacts with students (simultaneous physical couplings in the timespace) are irreplaceable. We feel that the quality of the educational process tends to be compromised in the virtual space that is, under current conditions, generally and easily available with financially affordable technologies. This situation appears to be in contrast to our research activities which do not seem to have been severely challenged by the new situation. For researchers already in the scientific community, then, physical contacts with colleagues are not as important as in the case of the teaching process. In a longer time perspective, however, research claiming personal meetings in empirical studies might be problematic, especially when the research problem concerns sensitive issues. New generations of researchers entering the scientific community will meet new kinds of coupling restrictions. We admit that these examples are subjective, reflecting our experiences, and we do not claim that they hold true generally. Nonetheless, it seems clear that some bundles in virtual time space can be less effective than others with respect to project accomplishment, which is also relevant for in-depth research. As indicated above, this is not only the case in education, but also of work (home office, telecommuting), shopping and social activities.

\subsection{The meaning of stations and paths}

Until recently, two traditional and basic time-geographic concepts, station and path, have been considered as concepts that needed to be assigned some added value (e.g. in the form of emotional load, quality of life, transport mode, etc.), but now they seem to have regained their original importance per se. One specific physical station, 'home', is garnering multiple meanings - a shelter (original meaning), an office or a workplace, a place for education and shopping, but also a cage. Perhaps as a result, other physical stations are losing their previous meanings. Speaking of home, what might be of interest now are the interactions between household members (from the point of view of age, sex, social roles, etc.) and the use of energy and consumption behaviours of households. Another interesting issue is the changing role of virtual "stations" (and portals, message windows: see Miller, 2005b), when virtual bundles are necessary. There may be a shift from the prevailing leisure function of virtual stations to 'must activities' functions. Thus, peoples' activities in virtual space may gain different qualities than before the pandemic. Hence, there is a need for a concept where "virtual stations" or "virtual bundles" are considered.

Until recently, the concept of (individual) path has been interpreted by many researchers only as a basic record of human existence in the time-space. In the pandemic situation, it seems that this spatio-temporal aspect comes to the fore again. This is particularly true for health issues and the already-mentioned backtracking of infected persons and the identification of respective bundles - possible sources of further infection spread. Here, we return to the roots of time-geography and Hägerstrand's research on the diffusion of innovations, where the virus is an innovation of nature, and migration, where peoples' movements and couplings in time and space serve as diffusion motors. It may be appealing to examine the reasons for a group of individuals, what were their choices of their particular paths, for their preferences or rejections of some directed path. Safety rather than any traditional geographical distance, speed or cost may prevail, when individuals seek their path through their prisms to move from one station to another. Additionally, the perspective of couplings between the human world and the environment is an increasingly important issue. As the areas occupied by human activities increase, wildlife meets hard restrictions (for example roads, buildings, fences) and thereby the prisms for animals and humans increasingly intersect, causing more coupling possibilities. This will increase the risk for new diseases to spread from animals to humans. 
In a longer temporal perspective, some intriguing questions for future time-geographic research are: What new routines will prevail after the pandemic has loosened its grip on humanity? How will people perform their activities to achieve the goals of their projects, and what stations will become more or less attractive than before? What lessons are learned in terms the importance of couplings and how they restrict daily life?

\subsection{Time-geography in the post-Covid era}

As the global pandemic has had a huge impact on human lives and its consequences are likely to be reflected in human behaviour for some time after it fades out, insights into time-space aspects of human behaviour in the Covid era brings new challenges also to time-geographic research, and the need to scrutinise again some of its theory and concepts arises as well. In this article, we have turned our attention to four aspects of time-geographic research, which can be related to the Covid pandemic and its future consequences. The role of time-geographic techniques to understand time-space processes and to track individual's existence in the time-space emerges once again. Routines, rhythms and random activities in the time-space reflect the framework 'set' by the pandemic and its impacts on everyday life, households, work, education, health, environmental and consumption issues. As a result, the importance of virtual bundles increases and many 'must activities' partly move onto the Web. Finding themselves in new situations, individuals may experience social and perceptual unease and stress, which can be felt differently in specific population groups (children, women, men, the disabled, etc.). Therefore, several time-geographic concepts seem to gain new qualities, significance and meaning, in particular the concepts of constraints, virtual space, bundles, paths and stations.

\section{Special Issue of the Moravian Geographical Reports on "Current issues, methods and applications in time-geography"}

The articles collected in this Special Issue address several key problems in time-geographic research. The original articles are based on pre-pandemic research: the date of the initial expression of authors' interest to participate and the submission of abstracts was November 30, 2019, and the deadline for submission of full articles was March 1, 2020 ${ }^{1}$. Nonetheless, there is a thematic affinity in these articles each one presenting new aspects and uses of the time-geographic approach, that respond in various degrees, to the questions and challenges raised above in this introductory article.

The first three articles take up some important issues for time-geographic research related to methodological questions. Two articles are concerned with ICT in general and potentially, tracking technologies. Mobile phone data are considered one of the most promising information sources for mapping the spatio-temporal activities of people. Large-scale mobile phone datasets are widely applied to monitor the daily life of urban populations and to examine the structuring of urban environments. Martin Šveda, Michala Sládeková Madajová, Peter Barlík, František Križan and Pavel Šuška, in their article, develop and discuss a methodological procedure that uses such data to observe temporal differences of the human presence in the city of Bratislava. The authors illustrate how the records of the mobile network infrastructure can be used as a suitable proxy variable for complex human activity at the city level, in the sense that they capture not only specific activities (such as the work cycle of a given locale, or shopping more generally) but various kinds of spatial practices. Stanislav Kraft, Tomáš Květoň, Vojtěch Blažek, Lukáš Pojsl and Jiří Rypl have mapped the daily mobility patterns of university students in an urban environment using time-space diaries, GPS loggers and smartphone applications. They analyse the spatial patterns of intra-urban mobility using basic mobility indicators (trips, distance, time), travel behaviour (use of transport modes) and specific time-space bundles (spaces of concentration of particular time-space trajectories). In doing so, they compare the three mentioned research methods and technologies according to their tracking accuracy and informative value, for the case study of České Budějovice in southern Bohemia, the Czech Republic

In the next article, Robert Osman, Vladimír Ira and Jakub Trojan discuss the limitations of existing methodological approaches to the comparison of time policies between cities, and the international comparisons of urban times in general. The authors introduce the approach of a comparative chronourbanism, providing the theoretical framing, systematic procedures and an empirical illustration of the comparison of urban times using the analysis of timetables of the cities of Brno (the Czech Republic) and Bratislava (Slovakia).

Next, we turn our attention to the rhythms of healthrelated activities, clearly principal issues in the pandemic era. At present, people with severe mental illness face different interventional landscapes compared to some decades ago, when mental hospitals dominated the Western world. Gunnel Andersson, Katerina Vrotsou, Anne Denhov, Alain Topor, Per Bülow and Kajsa Ellegård investigated people diagnosed with psychosis for the first time, over a 10-year period, and explored what interventions (defined as specific "spheres" in the article) men and women experienced. Based on data from registers and using a time-geographic representation, the authors visualised individuals in terms of their 10-year trajectories, where their transitions between the different spheres were highlighted. In the following article, which used a more qualitative approach, Eva Magnus, Klara Jakobsen and Randi Johansen Reidunsdatter demonstrate how timegeographic diaries, supplemented by in-depth interviews, can be effectively used to map and understand the daily activities and specific everyday life projects that improve the quality of life of breast cancer survivors. The findings of studies such as these, definitively can be implemented in the development of more individual and peer-driven health care services.

The following two articles are concerned with perceptions and social issues. The concept of topophobia has been known in Geography for decades (for example, Porteous, 1987). The perception of fear within an urban environment is often represented by fear of crime and it usually is exhibited in certain spatio-temporal concentrations. Petr Šimáček, Miloslav Šerý, David Fiedor and Lucia Brisudová deal in their article with the analysis of topophobic places in an urban environment. They focus on the temporal dimension of the fear of crime and show how the intensity of and the reasons for fears vary depending on time of day and place. In their

\footnotetext{
${ }^{1}$ Actually the day when the first three cases of the Covid-19 disease in the Czech Republic (the country where the MGR journal is
} published and where two of the authors of this paper live) were officially confirmed. 
article, Bohumil Frantál, Pavel Klapka and Eva Nováková study space-time constraints, isolation and the loneliness of older adults in urban environments. Their model of socialspatial isolation, based on data from space-time diaries and questionnaires, shows that isolation is significantly associated with the frequency of performing specific athome and out-of-home activities, which are constrained by age-related health condition, financial opportunities, spatial mobility and time consumption. This study supports the hypothesis that socio-spatial isolation is a multi-component, place-dependent and gendered issue.

In the last article, Chunjiang Li, Yanwei Chai and Yoshio Arai provide a summary of the diffusion and development of time-geography in East Asia, specifically in Japan and China. The authors tell the story about how and why time-geography diffused into East Asia by presenting and analysing the academic life paths of the two key scholars in the field. The effectiveness and disadvantages of the academic life path method as a tool in mapping the diffusion of a scientific discipline, is also discussed.

As a continuing thread throughout these articles, there is an inherent presence of uncertainty entering into everyday lives from the pandemic. As indicated recently by world renowned physicist Carlo Rovelli in The Guardian (Monday, 26 October, 2020): "Between certainty and complete uncertainty there is a precious intermediate space - and it is in this intermediate space that our lives and our decisions unfold". Perhaps, in the real world of everyday lives and choices, this very thin boundary zone can best be explored by time-geography.

This volume of articles represents the contemporary thematic diversity of research into time and space, including other disciplines than geography. It mirrors the ambitions of Hägerstrand to create a "language" that enables communication between disciplines. Additionally, both quantitative and qualitative approaches to time-geographic issues are documented. The articles show how the theory and methods of time-geography serve as an inspiration and relate to the application potential of Geography as a discipline. Thus, the reader is presented with various aspects of human behaviour in the time-space, its record, manifestation, consequences and implications, in brief, knowledge which can be used to resolve various aspects of current social problems.

\section{Acknowledgements}

This article has been elaborated in the scope of the project: "Spatial interactions and their conceptualisation: analysis of selectivity, uncertainty and hierarchy" [GA20-21360S] financed by the Czech Science Foundation and the long-term institutional support from the Institute of Geonics of the Czech Academy of Sciences [RVO: 68145535].

\section{References:}

AALBERS, M., BEEREPOOT, N. Y., GERRITSEN, M. (2020): Editorial: The geography of the Covid-19 pandemic. Tijdschrift voor Economische en Sociale Geografie, 111(3): 201-204.

ASGARI, H., JIN, X., ROJAS IV, M. B. (2019): Time-geography of daily activities: A closer look into telecommute impacts. Travel Behaviour and Society, 16: 99-107.
BOWLBY, S. (2012): Recognising the time-space dimensions of care: Caringscapes and carescapes. Environment and Planning A, 44(9): 2101-2118.

BROOKE, J., JACKSON, D. (2020): Older people and COVID-19: Isolation, risk and ageism. Journal of Clinical Nursing, 29: 2044-2046.

CARLSTEIN, T. (1982): Time resources, society and ecology: On the capacity for human interaction in space and time in preindustrial societies. Lund Studies in Geography B, 49. Stockholm, Gleerup.

CHEN, J., SHAW, S. L., YU, H., LU, F., CHAI, Y., JIA, Q. (2011): Exploratory data analysis of activity diary data: a space-time GIS approach. Journal of Transport Geography, 19(3): 394-404.

COUCLELIS, H. (2009): Rethinking time-geography in the information age. Environment and Planning A, 41(7): 1556-1575.

COUCLELIS, H., GOLLEDGE, R. G., GALE, N., TOBLER, W. (1987): Exploring the anchor-point hypothesis of spatial cognition. Journal of Environmental Psychology, 7(2): 99-122.

CRAIG, L., VAN TIENOVEN, T. P. (2019): Gender, mobility and parental shares of daily travel with and for children: a cross-national time use comparison. Journal of Transport Geography, 76: 93-102.

DAVIES, K. (2001): Responsibility and daily life. In: Jon May, J., Thrift, N. [eds.]: Timespace: geographies of temporality (pp. 133-148).London, Routledge.

DIJST, M. (2019): A relational interpretation of timegeography. In: Ellegård, K. [ed.]: Time-geography in the global context: An anthology (pp. 113-134). London, New York, Routledge.

DIXON, J., TREDOUX, C., DAVIES, G., HUCK, J., HOCKING, B., STURGEON, B., WHYATT, D., JARMAN, N., BRYAN, D. (2020): Parallel lives: Intergroup contact, threat, and the segregation of everyday activity spaces. Journal of Personality and Social Psychology, 118(3): 457-480.

DYCK, I. (1998). Women with disabilities and everyday geographies: Home space and the contested body. In: Kearns, R. A., Gesler, W. M. [eds.]: Putting health into place: landscape, identity and well-being (pp. 102-119). Syracuse, NY, Syracuse University Press.

ELLEGÅRD, K. (1999): A time-geographical approach to the study of everyday life of individuals - a challenge of complexity. GeoJournal, 48(3): 167-175.

ELLEGÅRD, K., VILHELMSON, B. (2004): Home as a pocket of local order. Geografiska Annaler B, 86(4): 281-296.

ELLEGÅRD, K. (2019a): Thinking time-geography: Concepts, methods and applications. London-New York, Routledge.

ELLEGÅRD, K. [ed.] (2019b): Time-geography in the global context: An anthology. London-New York, Routledge.

ELLEGÅRD. K. (2020): Time-Space Diaries. In: Kobayashi, A. [ed.]: International Encyclopedia of Human Geography (pp. 301-311). Elsevier.

FRANCH-PARDO, I., NAPOLETANO, B. M., ROSETEVERGES, F., BILLA, L. (2020): Spatial analysis and GIS in the study of COVID-19. A review. Science of the Total Environment, 739: 140033. 
FRANTÁL, B., KLAPKA, P. (2020): Exploring the nexus between place of residence, daily activity patterns and the socio-spatial isolation of mothers on parental leave. Area, 52(2): 401-410.

FRANTÁL, B., KLAPKA, P., SIWEK, T. (2012): Lidské chování v prostoru a čase: teoreticko-metodologická východiska. Sociologický časopis/Czech Sociological Review, 48(5): 833-857.

FREDERIKS, E., STENNER, K., HOBMAN, E. (2015): The socio-demographic and psychological predictors of residential energy consumption: A comprehensive review. Energies, 8(1): 573-609.

GAO, S., RAO, J., KANG, Y., LIANG, Y., KRUSE, J. (2020): Mapping county-level mobility pattern changes in the United States in response to COVID-19. SIGSpatial Special, 12(1): 16-26.

GAO, G., SAI, L. (2020). Towards a 'virtual' world: Social isolation and struggles during the COVID-19 pandemic as single women living alone. Gender, Work \& Organization, 27: 754-762.

GOLLEDGE, R. G., SPECTOR, A. N. (1978): Comprehending the urban environment: theory and practice. Geographical Analysis, 10(4): 403-426.

GOLLEDGE， R. G., STIMSON， R. J. (1997): Spatial behavior: A geographical perspective. New York-London, The Guilford Press.

GRAHAM, S. (1998): The end of geography or the explosion of place? Conceptualizing space, place and information technology. Progress in Human Geography, 22(2): 165-185.

GREN, M. (2001): Time-geography matters. In: May, J., Thrift, N. [eds.]: Timespace: Geographies of temporality (pp. 208-225). London, Routledge.

HÄGERSTRAND, T. (1950): Torp och backstugor i 1800-talets Asby. In: Hedkvist, E. et al. [eds.]: Från Sommabygd till Vätterstrand (pp. 30-38). Linköping, Tranås hembygdsgille.

HÄGERSTRAND, T. (1953): Innovationsförloppet ur korologisk synpunkt. Meddelanden från Lunds universitets geografiska institution 25. Lund, Gleerup.

HÄGERSTRAND, T. (1955): Statistiska primäruppgifter, flygkartering och dataprocessingmaskiner. Ett kombineringsprojekt. Svensk Geografisk Årsbok, 31: 233-255.

HÄGERSTRAND, T. (1957): Migration and area. Survey of a sample of Swedish migration fields and hypothetical considerations on their genesis. In: Hannerberg, D., Hägerstrand, T., Odeving, B. [eds.]: Migration in Sweden: A Symposium (pp. 27-158). Lund Studies in Geography B, 13. Lund, Gleerup.

HÄGERSTRAND, T. (1967): Innovation diffusion as a spatial process. Lund, Chicago, Gleerup-Chicago University Press. Translation and postscript by Allen Pred.

HÄGERSTRAND, T. (1970): What about people in regional science? Papers of the Regional Science Association, 24(1): 7-21.

HÄGERSTRAND, T. (1974): Tidsgeografisk beskrivning syfte och postulat. Svensk Geografisk Årsbok, 50: 86-94.

HÄGERSTRAND, T. (1976): Geography and the study of interaction between nature and society. Geoforum, 7(5-6): 329-344.
HÄGERSTRAND, T. (1982): Diorama, path and project. Tijdschrift voor economische en sociale geografie, 73(6): 323-339.

HÄGERSTRAND, T. (1985): Time-geography. Focus on the corporeality of man, society and environment. In: The Science and Praxis of Complexity (pp. 193-216). Tokyo, the United Nations University.

HÄGERSTRAND, T. (2009): Tillvaroväven. Stockholm, Formas.

HALL, S. M. (2019): Everyday austerity: Towards relational geographies of family, friendship and intimacy. Progress in Human Geography, 43(5): 769-789.

HALLIN, P. O. (1991): New paths for time-geography? Geografiska Annaler B, 73(3): 199-207.

ISAKSSON, C., ELLEGÅRD, K. (2015): Dividing or sharing? A time-geographical examination of eating, labour, and energy consumption in Sweden. Energy Research \& Social Science, 10: 180-191.

KLAPKA, P., HALÁS, M. (2016): Conceptualising patterns of spatial flows: Five decades of advances in the definition and use of functional regions. Moravian Geographical Reports, 24(2): 2-11.

KLAPKA, P., HALÁS, M., ERLEBACH, M., TONEV, P. BEDNÁŘ, M. (2014): A multistage agglomerative approach for defining functional regions of the Czech Republic: the use of 2001 commuting data. Moravian Geographical Reports, 22(4): 2-13.

KLAPKA, P., HALÁS, M., NETRDOVÁ, P., NOSEK, V. (2016): The efficiency of areal units in spatial analysis: Assessing the performance of functional and administrative regions. Moravian Geographical Reports, 24(2): 47-59.

KÖHLER, H., TRYGG, K. (2019): A time-geographical mixedmethods approach: studying the complexities of energy and water use in households. Fennia - International Journal of Geography, 197(1): 108-120.

KWAN, M. P. (2004): GIS methods in time-geography research: geocomputation and geovisualization of human activity patterns. Geografiska Annaler B, 86(4): 267-280.

LANDBY, E. (2019): Everyday travel for families with children using wheelchairs: parents' perceptions of constraints and adaptation strategies. Children's Geographies, 17(4): 388-400.

LEE, J. Y., KWAN, M. P. (2011): Visualisation of socio-spatial isolation based on human activity patterns and social networks in space-time. Tijdschrift voor economische en sociale geografie, 102(4): 468-485.

LEE, J., MILLER, H. J. (2019): Analyzing collective accessibility using average space-time prisms. Transportation Research Part D, 69: 250-264.

LEFEBVRE, H. (2004): Rhythmanalysis: Space, time, and everyday life. London, Continuum.

LENNTORP, B. (1976): Paths in space-time environments: a time-geographic study of movement possibilities of individuals. Lund Studies in Geography B, 44. Stockholm, Gleerup.

LENNTORP, B. (1999): Time-geography - at the end of its beginning. GeoJournal, 48(3): 155-158.

LENNTORP, B. (2004): Path, prism, project, pocket and population: an introduction. Geografiska Annaler B, 86(4): 223-226. 
LIAO, F. (2019): Space-time prism bounds of activity programs: a goal-directed search in multi-state supernetworks. International Journal of Geographical Information Science, 33(5): 900-921.

LIU, C., SUSILO, Y. O., DHARMOWIJOYO, D. B. (2018): Investigating intra-household interactions between individuals' time and space constraints. Journal of Transport Geography, 73: 108-119.

LONG, J.A. (2018): Modelling movement probabilities within heterogeneous spatial fields. Journal of Spatial Information Science, 2018(16): 85-116.

MANZO, L. K. C., MINELLO, A. (2020): Mothers, childcare duties, and remote working under COVID-19 lockdown in Italy: Cultivating communities of care. Dialogues in Human Geography, 10(2): 120-123.

MÅRTENSSON, S. (1979): On the formation of biographies in space-time environments. Lund Studies in Geography B, 47. Stockholm, Gleerup.

MCQUOID, J., DIJST, M. (2012): Bringing emotions to timegeography: The case of mobilities of poverty. Journal of Transport Geography, 23: 26-34.

MILLER, H. J. (2005a): A measurement theory for timegeography. Geographical analysis, 37(1): 17-45.

MILLER, H. J. (2005b): Necessary space - time conditions for human interaction. Environment and Planning B, 32(3): 381-401.

NEUTENS, T., SCHWANEN, T., WITLOX, F. (2011): The prism of everyday life: Towards a new research agenda for time-geography. Transport Reviews, 31(1): 25-47.

NICOLA, M., ALSAFI, Z., SOHRABI, C., KERWAN, A., ALJABIR, A., IOSIFIDIS, C., AGHA, M., AGHA, R. (2020): The socio-economic implications of the coronavirus and COVID-19 pandemic: a review. International Journal of Surgery, 78: 185-193.

OLIVER, N., LEPRI, B., STERLY, H., LAMBIOTTE, R., DELETAILLE, S., DE NADAI, M., ... \& COLIZZA, V. (2020). Mobile phone data for informing public health actions across the COVID-19 pandemic life cycle. Science Advances, 6(23): eabc0764.

PALM, J., ELLEGÅRD, K., HELLGREN, M. (2018): A cluster analysis of energy-consuming activities in everyday life. Building Research \& Information, 46(1): 99-113.

POOM, A., JÄRV, O., ZOOK, M., TOIVONEN, T. (2020). Covid-19 is spatial: ensuring that mobile big data is used for social good. Big Data \& Society, 7(2): 1-7.

PORTEOUS, J. D. (1987). Deathscape: Malcolm Lowry's topophobic view of the city. The Canadian Geographer, 31(1): 34-43.

PRED, A. (1977): The choreography of existence: Comments on Hägerstrand's time-geography and its usefulness. Economic geography, 53(2): 207-221.

PRED, A. (1984): Place as historically contingent process: Structuration and the time-geography of becoming places. Annals of the Association of American Geographers, 74(2): 279-297.

ROSE-REDWOOD, R., KITCHIN, R., APOSTOLOPOULOU, E., RICKARDS, L., BLACKMAN, T., CRAPMTON, J., ROSSI, U, BUCKLEY, M. (2020): Geographies of the Covid-19 pandemic. Dialogues in Human Geography, 10(2): 97-106.
SCHNELL, I., YOAV, B. (2001): The sociospatial isolation of agents in everyday life spaces as an aspect of segregation. Annals of the Association of American Geographers, 91(4): 622-636.

SCHÖNFELDER, S., AXHAUSEN, K. W. (2003): Activity spaces: measures of social exclusion? Transport Policy, 10(4): 273-286.

SCHWANEN, T., KWAN, M. P. (2008): The Internet, mobile phone and space-time constraints. Geoforum, 39(3): 1362-1377.

SCHWANEN, T., KWAN, M. P., REN, F. (2008): How fixed is fixed? Gendered rigidity of space-time constraints and geographies of everyday activities. Geoforum, 39(6): 2109-2121.

SHAW, S. L., YU, H. (2009): A GIS-based time-geographic approach of studying individual activities and interactions in a hybrid physical-virtual space. Journal of Transport Geography, 17(2): 141-149.

SHAW, S. L., YU, H., BOMBOM, L.S. (2008). A spacetime GIS approach to exploring large individualbased spatiotemporal datasets. Transactions in GIS, 12(4): 425-441.

SHEN, Y. (2019): Segregation through space: A scope of the flow-based spatial interaction model. Journal of Transport Geography, 76: 10-23.

SHEN, Y., CHAI, Y., KWAN, M. P. (2015): Space-time fixity and flexibility of daily activities and the built environment: A case study of different types of communities in Beijing suburbs. Journal of Transport Geography, 47: 90-99.

SHOVAL, N. (2008): Tracking technologies and urban analysis. Cities, 25(1): 21-28.

SHOVAL, N., KWAN, M. P., REINAU, K. H., HARDER, H. (2014): The shoemaker's son always goes barefoot: Implementations of GPS and other tracking technologies for geographic research. Geoforum, 51: 1-5.

SUI, D. (2012). Looking through Hägerstrand's dual vistas: towards a unifying framework for time-geography. Journal of Transport Geography, 23: 5-16.

SUOMALAINEN, K., EYERS, D., FORD, R., STEPHENSON, J., ANDERSON, B., JACK, M. (2019): Detailed comparison of energy-related time-use diaries and monitored residential electricity demand. Energy and Buildings, 183: 418-427.

ŠVEDA, M., MADAJOVÁ, M. (2012): Changing concepts of time-geography in the era of information and communication technologies. AUPO Geographica, 43(1): 15-30.

ŠVEDA, M., MADAJOVÁ, M. (2015): Merging diaries and GPS records: The method of data collection for spatiotemporal research. Moravian Geographical Reports, 23(2): 12-25.

THRIFT, N. (1977): An introduction to time-geography. CATMOG 13. Norwich, Geo Abstracts.

THRIFT, N., PRED, A. (1981): Time-geography: a new beginning. Progress in Human Geography, 5(2): 277-286.

THULIN, E., VILHELMSON, B. (2005): ICT-based activities among young people - user strategies in time and space. Tijdschrift voor economische en sociale geographie, 96(5): 477-487. 
THULIN, E., VILHELMSON, B. (2012): The virtualization of urban young people's mobility practices: a time-geographic typology. Geografiska Annaler B, 94(4): 391-403.

THULIN, E., VILHELMSON, B. (2019): Bringing the background to the fore: time-geography and the study of mobile ICTs in everyday life. In: Ellegĺrd, K. [ed.]: Timegeography in the global context: An anthology (pp. 96112). London-New York, Routledge.

THULIN, E., VILHELMSON, B., JOHANSSON, M. (2019): New telework, time pressure, and time use control in everyday life. Sustainability, 11(11): 3067.

THULIN, E., VILHELMSON, B., SCHWANEN, T. (2020): Absent friends? Smartphones, mediated presence, and the recoupling of online social contact in everyday life. Annals of the American Association of Geographers, 110(1): 166-183.

TIMMERMANS, H., ARENTZE, T., JOH, C. H. (2002): Analysing space-time behaviour: new approaches to old problems. Progress in Human Geography, 26(2): 175-190.

TYNER, J., RICE, S. (2020). Meaningful life in the time of Corona-economics. Dialogues in Human Geography, 10(2): 116-119.

VILHELMSON, B. (1999): Daily mobility and the use of time for different activities. The case of Sweden. GeoJournal, 48(3): 177-185.

VILHELMSON, B., THULIN, E. (2008): Virtual mobility, time use and the place of the home. Tijdschrift voor economische en sociale geografie, 99(5): 602-618.
WILES, J. (2003): Daily geographies of caregivers: mobility, routine, scale. Social Science \& Medicine, 57(7): 1307-1325.

YANTZI, N. M., ROSENBERG, M. W. (2008): The contested meanings of home for women caring for children with long-term care needs in Ontario, Canada. Gender, Place and Culture, 15(3): 301-315.

YIN, Z. C., WU, Y., WINTER, S., HU, L. F., HUANG, J. J. (2018): Random encounters in probabilistic timegeography. International Journal of Geographical Information Science, 32(5): 1026-1042.

YU, H. (2006): Spatio-temporal GIS design for exploring interactions of human activities. Cartography and Geographic Information Science, 33(1): 3-19.

YU, H., SHAW, S. L. (2007): Revisiting Hägerstrand's timegeographic framework for individual activities in the age of instant access. In: Miller, H. J. [ed.]: Societies and cities in the age of instant access. The Geojournal Library, 88 (pp. 103-118). Dordrecht, Springer.

YUAN, H., CHEN, B. Y., LI, Q., SHAW, S. L., LAM, W. H. (2018): Toward space-time buffering for spatiotemporal proximity analysis of movement data. International Journal of Geographical Information Science, 32(6): 1211-1246.

\section{Please cite this article as:}

KLAPKA, P., ELLEGÅRD, K., FRANTÁL, B. (2020): What about Time-Geography in the post-Covid-19 era? Moravian Geographical Reports, 28(4): 238-247. Doi: https://doi.org/10.2478/mgr-2020-0017 